\title{
Studies on the Compatibility between Lincomycin and Kitassamycin in the Control of Necrotic Enteritis in Broiler Chickens
}

\author{
Hala M Kalillı ${ }^{*}$, Amira Samir Mohamed ${ }^{2}$, Hala A El Said ${ }^{1}$, Halla Salah ${ }^{1}$ and Mona Salh El Deen ${ }^{3}$ \\ ${ }^{1}$ Biochemistry department, Animal Health Research Institute (Zagazig Branch) Agriculture research center, Egypt \\ ${ }^{2}$ Bacteriology department, Animal Health Research Institute (Zagazig Branch) Agriculture research center, Egypt \\ ${ }^{3}$ Clinical pathology department, Animal Health Research Institute (Zagazig Branch) Agriculture research center, Egypt \\ *Corresponding Author: Hala M Kalill, Biochemistry department, Animal Health Research Institute (Zagazig Branch) Agriculture \\ research center, Egypt.
}

Received: January 07, 2022; Published: January 28, 2022

\begin{abstract}
A total of 75 one-day old broiler chickens were used in this study for investigate compatibility between Lincomycin and Kitasamycin for treating clostridium perfringens infection and its effects in hematobiochemical parameters. At day 15 of age broilers were divided into 5 equal groups. Chicks in groups $(2,3,4$ and 5$)$ were infected with clostridium perfringens type $C$, $1^{\text {st }}$ group non-infected, non-treated (-ve control), $2^{\text {nd }}$ group-infected non-treated(+ve control), $3^{\text {rd }}$ group infected lincomycin treated for 5 days, $4^{\text {th }}$ group infected kitasamycin treated for 5 days and $5^{\text {th }}$ group infected treated with both drugs together by same dose and period. At $1^{\text {st }}$ day post treatment 2 blood sample was taken from all birds for hematobiochemical study. Infected broilers showed clinical signs as loss of appetite ruffled feathers, depression, loss of appetite, diarrhea, dehydration, polydipsia, emaciation, significant reduction in body weight gain total protein, albumin, catalase and superoxide dismutase beside significant increase in mortality rate, feed conversion rate, leukocytic count, heterophile, lymphocyte, monocyte, eosinophile, basophile, phagocytosis and index, liver enzyme (aspartate aminotransferase, alanine aminotransferase, alkaline phosphatase) uric acid, creatinine, malanodialdhyde coupled with insignificant increase in total globulin, alpha, beta and gamma globulin beside insignificant decrease in total lipids, triglycerides and cholesterol. Necrotic entritits induced many pathological leion in liver, kidney and intestine Treatment infected broilers using lincomycin and kitassmycin lead to improved in hematobiochemical parameter and reduction in clostridium perfringens counts in faeces and bacterial reiolation but infected broilers treated with both drugs together showed superior improvement in hematobiochemical parameter. It could be concluded that Combination of lincomycin and kitassmycin is effective in treatment necrotic entritis than each alone.
\end{abstract}

Keyword: Clostridium perfringens; Lincomycin; Kitasamycin; Broilers; Pathology

\section{Introduction}

Poultry diseases cause severe losses to poultry industry by increasing mortality reducing weight gain [12] clostridium perfringens is the most important clostridial pathogen of poultry [24]. It is a fatal disease and its mortality rates about 30\% [56]. Its produced serious disease in chicks named necrotic enteritis [54]. The disease occured in broilers 2-6 weeks of age and is characterized by sudden onset of diarrhea and mucosal necrosis [38] Antibiotics are widely used in veterinary practice to overcome bacterial infections in poultry. In many parts of the world, food-producing animals are given antibiotics daily to make them grow faster and prevent diseases [55]. 
Among well developed antibiotics that seem promising in veterinary use are lincomycin and Kitassamycin [51]. Antibiotics are used as therapeutic agents for treatment of infectious diseases in humans and livestock [31].

Lincomycin is a member of aminooglycoside antibiotic that inhibits protein synthesis by binding to 50s ribos-omal subunit and has specific activity aganist closterdial infection [25 \& 44]. It is used in treatment of bacterial enteric infections [4]. Macrolide antibiotics are a group of antibiotics widely used to treat and prevent diseases and promote growth in food-producing animals [47]. Macrolides has antimicrobial activity by inhibiting protein synthesis. Macrolides are bacteriostatic active against Gr+ve and Gr-ve bacteria [22]. Kitassamycin is a member of macrolide antibiotic, has high degree of efficacy in control disease as it a wide tissue distribution and high intracellular concentration [2].

This study was planned to investigate the effect of Lincomycin and Kitasamycin for treating clostridium perfringens infection in broilers with regarding to its effects in some biochemical parameters in broilers as well as pathological changes.

\section{Materials and Methods}

Drugs

1. kitasamycin tartarate water soluble powder (100gm/packag) obtained from ADWIA Comp. for Pharmaceuticals SAE administered orally at dose $1 \mathrm{gm} /$ liter drinking water.

2. Lincomycin hydrochloride (atolinc $40 \%)^{\mathrm{R}}$ produced from Atico company administ-ered orally at a dose of $0.5 \mathrm{gm} / \mathrm{liter} \mathrm{drinking}$ water.

\section{Closterdium infection}

At $15^{\text {th }}, 17^{\text {th }}$ and $19^{\text {th }}$ day of age chicks in group (2, 3, 4 and 5) were administered three oral inocula-tion of $2 \mathrm{ml}$ freshly prepared 24 hrs incubated thioglycolate broth culture of clostridium perfringens type C $\left(1.5 \times 10^{9}\right)$ organisms $\left./ \mathrm{ml}\right)[13]$.

\section{Birds and Experimental design}

A total of 75, one-day old Hubbard broiler chicks were used in this trial. Chicks were floor reared in separate units under hygienic measures. All chicks were vaccinated with Newcastle vaccines and Gumboro vaccine at 14 day. Broilers feed ration obtained from El-Kahera Poultry Comp. At day 15 of age broilers were divided into 5 groups (15 each) $1^{\text {st }}$ group non-infected, non-treated (-ve control). $2^{\text {nd }}$ group infected with clostridium perfringens non-treated (+ve control), $3^{\text {rd }}$ group infected with clostridium perfringens treated with $1 \mathrm{gm} /$ liter lincomycin, $4^{\text {th }}$ group infected with clostridium perfringens treated with $10 \mathrm{mg} / \mathrm{Kgm}$ Bwt kitasamycin in drinking water, $5^{\text {th }}$ group infected with clostridium perfringens treated with lincomycin and kitasamycin together by same dose and period. Treatment started in all groups at $21^{\text {th }}$ day of age for 5 successive days.

Body weight all broilers were weighted individually at start of experiment and at $1^{\text {st }}$ day post treatment for calculation weight gain and feed conversion rate.

Blood samples At $1^{\text {st }}$ day post treatment 5 broilers from each groups were sacrificed and two blood samples from each bird were tacken.

$1^{\text {st }}$ sample was taken in tub contain EDTA, used for determination total and differential leucocytic count according [30], phagocytosis\% and phagocytic index according [46 \& 58].

$2^{\text {nd }}$ sample was tacking in centrifuge tube for obtain clear serum for. estimation total protein [17], serum protein fractions were performed using cellulose acetate electrophoresis test [26]. laspartate aminotransferase and alanine aminotransferase were Determined according [45], alkaline phosphatase [33]. Serum uric acid [23], creatinine [29], total lipid [37], Cholesterol [10], Triglyceride [57], 
super oxide dismutase [43], Catalase [50] and malanodialdhyde [42].

\section{Counting of Clostridium perferenges}

Post chicks sacrificed 1gram faeces from each chicks was placed in sterile tube for clostridium perfringens counting pre treatment and at 1st day post treatment [39].

\section{Re-isolation of clostridium perferenges}

Loopfulls from intestine were inoculated asepetically into cooked meat broth then incubated anaerobically at $37^{\circ} \mathrm{C}$ for $48 \mathrm{~h}$. Then a loopful was inculated on agar plates cont-ain $10 \%$ sheep blood and $10 \%$ gentamycin and this plates were incubated anaerobically at $37^{\circ} \mathrm{C}$ for $48 \mathrm{~h}$. Colonies were identified morphologically and biochemically [16].

\section{Histopathological studies}

Post chicks sacrificed sample from Liver, kidney and intestine were taken, fixed in $10 \%$ formaline solution. Collected samples were dehydrated and embedded in paraffin wax, then sectioned to 4 micron thickness, stained by H\&E and examined microscopically [14].

\section{Statistical analysis}

Obtained data was analyzed by using computerized SPSS program version 16 according to [53].

\section{Results and Discussion}

Broilers suffering from necrotic entrititis showed clinical sign as loss of appetite, diarrhea, depression, ruffled feather, polydipsia, dehydration, emaciation, increase mortality rate beside reduction in body weight gain, food intake and increase in feed conversion rate. Beside increase clostridium perfringens counts in faeces at pre-treatment and increase reisolation of clostridium perfringens in infected non treatment (Table 1 and 2). Our findings coordinates with [4] reported that broiler suffering from necrotic entrititis showed reduction in body weight gain, loss of appetite, diarrhea, depression, ruffled feather, polydipsia, dehydration. These clinical signs and reduction in weight gain were observed [7] in broiler chickens suffering from necrotic entritis. Same clinical signs were observed in broilers suffering from necrotic entrititis [19 \& 9].

\begin{tabular}{|c|c|c|c|c|c|c|}
\hline \multirow{2}{*}{$\begin{array}{c}\text { Parameter } \\
\end{array}$} & \multicolumn{2}{|c|}{$\begin{array}{c}\text { Mortality rate } \\
\text { (10 bird/group) }\end{array}$} & \multicolumn{2}{c|}{$\begin{array}{c}\text { clostridium perfringens counts/gm } \\
\text { Faeces (5 bird/group) }\end{array}$} & \multicolumn{2}{c|}{$\begin{array}{c}\text { clostridium perfringens } \\
\text { Re-isolation (5 bird/group) }\end{array}$} \\
\cline { 2 - 7 } & $\mathbf{N o}$ & $\mathbf{\%}$ & Pre treatment & $\mathbf{1}^{\text {st day post treatment }}$ & No & 00 \\
\hline control & 00 & 00 & 00 & 00 & 5 & 100 \\
\hline Inf. non treated & 3 & 30 & $8.38 \pm 1.47 \mathrm{a}$ & $8.38 \pm 1.47 \mathrm{a}$ & 2 & 40 \\
\hline Inf. Linco. treated & 1 & 10 & $9.97 \pm 1.46 \mathrm{a}$ & $3.27 \pm 0.89 \mathrm{~b}$ & 2 & 40 \\
\hline Inf. Kitasa. treated & 1 & 10 & $8.68 \pm 1.55 \mathrm{a}$ & $2.61 \pm 1.03 \mathrm{~b}$ & 00 & 00 \\
\hline Inf. kitasa \& linco & 00 & 00 & $9.51 \pm 1.48 \mathrm{a}$ & $0.71 \pm 0.08 \mathrm{~b}$ & 00 & 0 \\
\hline
\end{tabular}

Means with different superscripts of the same raw indicate significant difference at $\mathrm{P}<0.05$

Table 1: The effect of lincomycin and kitasamycin on Mortality rate, clostridium perfringens reisolation and counts/gm faeces (Log 10).(5 bird/group). 
Studies on the Compatibility between Lincomycin and Kitassamycin in the Control of Necrotic Enteritis in Broiler Chickens

\begin{tabular}{|c|c|c|c|c|c|}
\hline $\begin{array}{c}\text { Parameters } \\
\text { Group }\end{array}$ & initial weight (15 day age) & Body weight & Weight gain & FC & F.C.R \\
\hline 475.20 & $367.89 \pm 2.79 \mathrm{a}$ & $818.84 \pm 3.98 \mathrm{a}$ & $450.95 \pm 1.93 \mathrm{a}$ & control & 1.30 \\
\hline 454.10 & $339.74 \pm 2.98 \mathrm{~b}$ & $795.62 \pm 2.78 \mathrm{~b}$ & $455.88 \pm 2.93 \mathrm{a}$ & Inf. non treated & 1.34 \\
\hline 475.08 & $359.90 \pm 2.87 \mathrm{~b}$ & $816.64 \pm 2.83 \mathrm{a}$ & $453.74 \pm 1.61 \mathrm{a}$ & Inf. Linco. treated & 1.32 \\
\hline 473.58 & $357.54 \pm 2.89 \mathrm{~b}$ & $815.52 \pm 3.98 \mathrm{a}$ & $457.98 \pm 1.72 \mathrm{a}$ & Inf. Kitasa. treated & 1.32 \\
\hline 480.97 & $369.01 \pm 3.97 \mathrm{~b}$ & $820.48 \pm 3.84 \mathrm{a}$ & $451.47 \pm 1.69 \mathrm{a}$ & Inf. kitasa \& linco & 1.30 \\
\hline
\end{tabular}

Means with different superscripts of the same raw indicate significant difference at $\mathrm{P}<0.05$

Table 2: The effect of lincomycin and kitasamycin on body performance in chickens infected with clostridium perfringens $(n=5)$.

Its clear evident from table (3) revealed that broilers suffering from necrotic entrititis showed significant increase in leukocyte, heterophil, lymphocyte esinophiles, basophils, monocyte, phagocytic activity and phagocytic index. Our data fit with those recorded [18] stated that changes in leukogram in broilers suffering from necrotic enteritis may be due to bacterial toxin. Same change in phagocytosis\% and index was recorded by [48] in chickens suffering from necrotic entrititis. Similar result was observed [36] in broilers. Broilers suffering from necrotic entrititis revealed significant increase in leukocytic, phagocytosis\% and index [35].

\begin{tabular}{|c|c|c|c|c|c|c|c|}
\hline \multicolumn{3}{|c|}{ Parameter } & Control & $\begin{array}{l}\text { Inf non } \\
\text { treated }\end{array}$ & $\begin{array}{c}\text { Inf. linco } \\
\text { treated }\end{array}$ & $\begin{array}{c}\text { Inf. kitasa } \\
\text { treated }\end{array}$ & $\begin{array}{c}\text { Inf. Lin \& kit } \\
\text { treated }\end{array}$ \\
\hline \multirow{6}{*}{$\begin{array}{c}\text { leukoctic } \\
\text { count }\left(\mathrm{X} 10^{3} /\right.\end{array}$} & \multicolumn{2}{|c|}{ Total WBCs } & $10.98 \pm 0.38 b$ & $13.73 \pm 0.58 a$ & $12.23 \pm 0.89 \mathrm{~b}$ & $12.21 \pm 0.74 b$ & $12.10 \pm 0.81 b$ \\
\hline & \multirow{5}{*}{$\begin{array}{c}\text { Deferential } \\
\text { count }\end{array}$} & heterophils & $2.44 \pm 0.13 b$ & $2.97 \pm 0.14 \mathrm{a}$ & $2.62 \pm 0.30 \mathrm{~b}$ & $2.59 \pm 0.25 b$ & $2.61 \pm 0.37 \mathrm{~b}$ \\
\hline & & lymphocyte & $3.50 \pm 0.18 b$ & $4.24 \pm 0.20 \mathrm{a}$ & $3.83 \pm 0.21 b$ & $3.80 \pm 0.30 \mathrm{~b}$ & $3.76 \pm 0.43 b$ \\
\hline & & monocyte & $1.54 \pm 0.17 b$ & $2.13 \pm 0.14 \mathrm{a}$ & $1.92 \pm 0.29 b$ & $1.93 \pm 0.26 b$ & $1.89 \pm 0.31 b$ \\
\hline & & eosinophils & $1.77 \pm 0.15 b$ & $2.33 \pm 0.17 a$ & $1.98 \pm 0.27 b$ & $1.97 \pm 0.29 b$ & $1.94 \pm 0.44 \mathrm{~b}$ \\
\hline & & Basophils & $1.73 \pm 0.11 b$ & $2.09 \pm 0.10 \mathrm{a}$ & $1.91 \pm 0.25 b$ & $1.92 \pm 0.31 b$ & $1.89 \pm 0.27 b$ \\
\hline \multicolumn{3}{|c|}{ phagocytosis $\%$} & $63.21 \pm 1.83 b$ & $68.55 \pm 1.34 \mathrm{a}$ & $65.21 \pm 1.73 b$ & $65.62 \pm 1.55 b$ & $64.43 \pm 1.55 b$ \\
\hline \multicolumn{3}{|c|}{ Phagocytic index } & $4.47 \pm 0.68 b$ & $6.62 \pm 0.41 \mathrm{a}$ & $5.24 \pm 0.61 b$ & $5.40 \pm 0.44 b$ & $4.87 \pm 0.64 b$ \\
\hline
\end{tabular}

Means with different superscripts of the same cullum indicate significant difference at $\mathrm{P}<0.05$

Table 3: effect of lincomycin and kitasamycin on leukogram, phagocytic activity \% and index in chickens infected with clostridium perfringens $(\mathrm{n}=5)$.

In the present investigation, it has been shown that broilers suffering from necrotic entrititis showed significant reduction in total protein and albumin associated with insignificant increase in total, $\mathrm{a}, \mathrm{b}$ and g globulin and insignificant decrease in $\mathrm{A} / \mathrm{G}$ ratio (table 4). Broilers suffering from necrotic enteritis showed decrease in total protein, albumin and globulin in due to anorexia and male absorption of nutrients from inflamed intestine or due to inability of liver to protein synthesis [34]. Our observed data are fit with [40 \& 6] reported that necrotic enteritis induced significant reduction in total protein and albumin. Broilers suffering from necrotic entritis show-ed decrease in total protein and albumin associated with insignificant increase in gamma globulin and insignificant decrease in alpha, beta globulin (35). Broilers uffering from necrotic entritis showed significant reduction in total protein, albumin and globulin [5]. 
Studies on the Compatibility between Lincomycin and Kitassamycin in the Control of Necrotic Enteritis in Broiler Chickens

\begin{tabular}{|c|c|c|c|c|c|c|}
\hline \multicolumn{2}{|c|}{ Parameter } & control & Inf non treated & Inf. Linco treated & Inf. kitasa treated & Inf. linco \& kitasa treated \\
\hline \multirow{2}{*}{ T.Protein } & $6.99 \pm 0.22 \mathrm{a}$ & $5.19 \pm 0.21 \mathrm{~b}$ & $6.09 \pm 0.26 \mathrm{~b}$ & $6.01 \pm 0.18 \mathrm{~b}$ & $6.70 \pm 0.32 \mathrm{a}$ \\
\hline \multicolumn{2}{|c|}{ Albumin } & $3.70 \pm 0.28 \mathrm{a}$ & $2.15 \pm 0.21 \mathrm{~b}$ & $2.69 \pm 0.20 \mathrm{~b}$ & $2.70 \pm 0.19 \mathrm{~b}$ & $3.38 \pm 0.35 \mathrm{a}$ \\
\hline \multirow{4}{*}{ Globulin } & $\mathrm{a}$ & $0.70 \pm 0.08 \mathrm{a}$ & $0.66 \pm 0.09 \mathrm{a}$ & $0.75 \pm 0.06 \mathrm{a}$ & $0.75 \pm 0.09 \mathrm{a}$ & $0.75 \pm 0.07 \mathrm{a}$ \\
\cline { 2 - 7 } & $\mathrm{b}$ & $0.79 \pm 0.07 \mathrm{a}$ & $0.78 \pm 0.08 \mathrm{a}$ & $0.86 \pm 0.07 \mathrm{a}$ & $0.82 \pm 0.06 \mathrm{a}$ & $0.85 \pm 0.09 \mathrm{a}$ \\
\cline { 2 - 7 } & $\mathrm{g}$ & $1.80 \pm 0.17 \mathrm{a}$ & $1.80 \pm 0.16 \mathrm{a}$ & $1.89 \pm 0.14 \mathrm{a}$ & $1.83 \pm 0.15 \mathrm{a}$ & $1.82 \pm 0.17 \mathrm{a}$ \\
\cline { 2 - 7 } & total & $3.29 \pm 0.62 \mathrm{a}$ & $3.04 \pm 0.54 \mathrm{a}$ & $3.33 \pm 0.62 \mathrm{a}$ & $3.31 \pm 0.52 \mathrm{a}$ & $3.32 \pm 0.48 \mathrm{a}$ \\
\hline \multicolumn{2}{|c|}{ A/G ratio } & $1.12 \pm 0.22 \mathrm{a}$ & $0.79 \pm 0.18 \mathrm{a}$ & $0.81 \pm 0.19 \mathrm{a}$ & $0.85 \pm 0.20 \mathrm{a}$ & $0.86 \pm 0.23 \mathrm{a}$ \\
\hline
\end{tabular}

Means with different superscripts of the same cullum indicate significant difference at $\mathrm{P}<0.05$

Table 4: The effect of lincomycin and kitasamycin on serum protein picture in chickens infected with clostridium perfringens $(n=5)$.

In present investigation, it has been shown that infected broilers with clostridium perfringens showed significant increase in liver enzymes (apartate aminotranferae, alanine aminotranferae and alkaline phosphatae) uric acid, creatinine beside insignificant decrease in total lipids, triglycerides and cholesterol (table 5). Our results were supported by the results reported [1] reported that broilers suffering from necrotic entritis showed increase in liver enzymes, uric acid and creatinine beside insignificant decrease total lipids, triglycerides and cholesterol. Same observation was recored [49] observed that necrotic entrititis induced significant increase in liver enzymes, uric acid, creatinine. Necrotic entritis induced decrease in serum total lipids, triglycerides and cholesterol [28]. Liver enzymes uric acid and creatinin were increased in broiler chickens suffering from necrotic entritis [35].

\begin{tabular}{|c|c|c|c|c|c|c|}
\hline \multicolumn{2}{|c|}{ Parameter } & Control & Inf non treated & $\begin{array}{c}\text { Inf. Linco } \\
\text { treated }\end{array}$ & $\begin{array}{c}\text { Inf. kitasa } \\
\text { treated }\end{array}$ & $\begin{array}{c}\text { Inf. linco \& kitasa } \\
\text { treated }\end{array}$ \\
\hline \multirow{2}{*}{$\begin{array}{c}\text { Liver } \\
\text { enzymes } \\
\text { (U/L) }\end{array}$} & AST & $42.17 \pm 1.25 \mathrm{~b}$ & $47.32 \pm 1.32 \mathrm{a}$ & $44.63 \pm 1.22 \mathrm{~b}$ & $44.64 \pm 1.21 \mathrm{~b}$ & $42.83 \pm 1.44 \mathrm{~b}$ \\
\cline { 2 - 7 } & ALT & $64.72 \pm 0.78 \mathrm{~b}$ & $67.22 \pm 0.55 \mathrm{a}$ & $64.18 \pm 0.57 \mathrm{~b}$ & $65.32 \pm 0.71 \mathrm{~b}$ & $64.12 \pm 0.66 \mathrm{~b}$ \\
\hline \multirow{2}{*}{$\begin{array}{c}\text { Kidney func- } \\
\text { tion }\end{array}$} & ALP & $56.78 \pm 0.89 \mathrm{~b}$ & $61.33 \pm 0.96 \mathrm{a}$ & $58.21 \pm 0.82 \mathrm{~b}$ & $58.55 \pm 0.77 \mathrm{~b}$ & $57.62 \pm 0.59 \mathrm{~b}$ \\
\cline { 2 - 7 } & Creatinine & $1.38 \pm 0.16 \mathrm{~b}$ & $2.14 \pm 0.15 \mathrm{~b}$ & $1.59 \pm 0.16 \mathrm{~b}$ & $1.55 \pm 0.13 \mathrm{~b}$ & $1.46 \pm 0.16 \mathrm{~b}$ \\
\hline \multirow{2}{*}{$\begin{array}{c}\text { lipid profile } \\
\text { (mg/dl) }\end{array}$} & T. lipid & $214.14 \pm 2.99 \mathrm{a}$ & $211.17 \pm 1.89 \mathrm{a}$ & $212.48 \pm 1.88 \mathrm{a}$ & $210.43 \pm 1.81 \mathrm{a}$ & $212.39 \pm 1.93 \mathrm{a}$ \\
\cline { 2 - 7 } & cholestrol & $86.38 \pm 1.84 \mathrm{a}$ & $82.34 \pm 1.28 \mathrm{a}$ & $84.55 \pm 1.27 \mathrm{a}$ & $84.71 \pm 1.66 \mathrm{a}$ & $857.0 \pm 1.88 \mathrm{a}$ \\
\cline { 2 - 7 } & triglyceride & $123.17 \pm 1.95 \mathrm{a}$ & $119.18 \pm 1.78 \mathrm{a}$ & $120.88 \pm 1.69 \mathrm{a}$ & $121.12 \pm 1.56 \mathrm{a}$ & $121.88 \pm 1.89 \mathrm{a}$ \\
\hline
\end{tabular}

Means with different superscripts of the same cullum indicate significant difference at $\mathrm{P}<0.05$

Table 5: The effect of lincomycin and kitasamycin on serum Liver enzymes, Kidney function and lipid profil in chickens infected with clostridium perfringens $(\mathrm{n}=5)$.

Infected broilers with clostridium perfringens showed significant reduction in catalase and super oxide dismutase beside significant increase malanodialdhyde (table 6). Increase in malanodialdhyde and reduction in catalase, super oxide dismutase in broilers suffering from necrotic entritis may be due to increase oxidative stress iduced by clostridium perfringens bacteria [32]. Our finding confirmed by those obtained [8] found that necrotic entritis induced reduction in catalase, super oxide dismutase and increase in malanodialdhyde in broilers. Same changes in antioxidant enzymes were reported [52] in broilers suffering from necrotic entritis. 
Studies on the Compatibility between Lincomycin and Kitassamycin in the Control of Necrotic Enteritis in Broiler Chickens

\begin{tabular}{|c|c|c|c|c|c|c|}
\hline \multicolumn{2}{|c|}{ Parameter } & Control & Inf non treated & $\begin{array}{l}\text { Inf. Linco } \\
\text { treated }\end{array}$ & $\begin{array}{l}\text { Inf. kitasa } \\
\text { treated }\end{array}$ & $\begin{array}{c}\text { Inf. linco \& kita- } \\
\text { sa treate }\end{array}$ \\
\hline \multicolumn{2}{|c|}{$\mathrm{MDA}(\mathrm{mmol} / \mathrm{ml})$} & $19.80 \pm 1.51 \mathrm{~b}$ & $24.61 \pm 1.24 a$ & $22.16 \pm 1.81 b$ & $21.99 \pm 1.72 b$ & $21.18 \pm 1.83 b$ \\
\hline \multirow{2}{*}{$\begin{array}{l}\text { antioxidant } \\
\text { enzymes }\end{array}$} & CAT $(\mathrm{U} / \mathrm{mL})$ & $42.08 \pm 1.89 \mathrm{a}$ & $35.03 \pm 1.93 \mathrm{~b}$ & $40.21 \pm 1.73 a$ & $40.74 \pm 1.65 a$ & $41.32 \pm 1.77 a$ \\
\hline & $\mathrm{SOD}(\mathrm{U} / \mathrm{mL}$ & $190.62 \pm 1.29 a$ & $184.05 \pm 1.44 \mathrm{~b}$ & $187.21 \pm 1.81 \mathrm{a}$ & $41.32 \pm 1.77 \mathrm{a}$ & $188.50 \pm 1.89 a$ \\
\hline
\end{tabular}

Means with different superscripts of the same cullum indicate significant difference at $\mathrm{P}<0.05$

Table 6: The effect of lincomycin and kitasamycin on serum lipid profile, serum malanodialdhyde and antioxidant enzymes in chickens infected with clostridium perfringens $(\mathrm{n}=5)$.

Concerning the histopathological changes, the liver of broilers uffering from necrotic entritis show congestion of hepatic blood vessels (Fig 1), fibrosis in portal area and hyperplastic bile duct epithelium (Fig 2). Necrotic epithelial lining villi and desquamation of intetine ((Fig 3), necrotic epithelial lining villi, desquamation and presence of heterophilic and lymphocytic infiltration in the lamina propria and submucosa (Fig 4). Kidney showed subscapular aggregation of lympho-cytes, renal papillae show-ed perivascular edema (Fig 5), shrinkage of moderate number of glomeruli and degenera-tive changes mainly hydropic degeneration in renal tubular epithelium (Fig 6). Liver of infected broilers lincomycin and kitasamycin treated together showed normal structures with hydropic degeneration in hepatocytes (Fig 7) normal structures with focal villous basal cells proliferation (Fig 8), Same lesion was observed [15 \& 11] in broilers suffering and duckling suffering from necrotic enteritis. Our findings are agreed with [4] mentioned that broilers suffering from necrotic entritits showed congestion of hepatic blood vessels and hydropic degeneration in renal tubular epithelium.

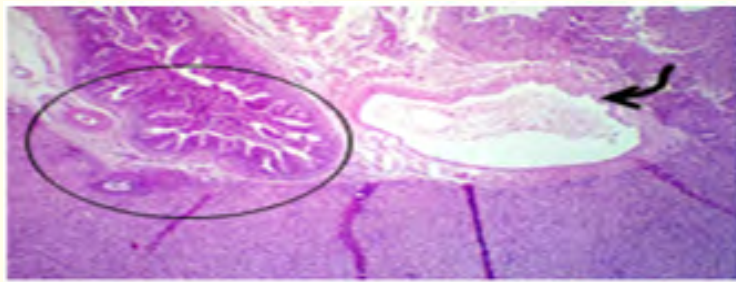

Figure 1: liver of infected broilers by cl perfringens showing sever congestion of hepatic blood vessels (curved arrow).

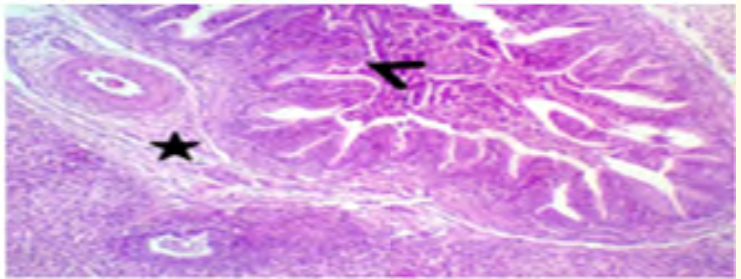

Figure 2: liver of infected broilers by cl perfringens showing portal area showing fibrosis (star) and hyperplastic bile duct epithelium (arrow head).

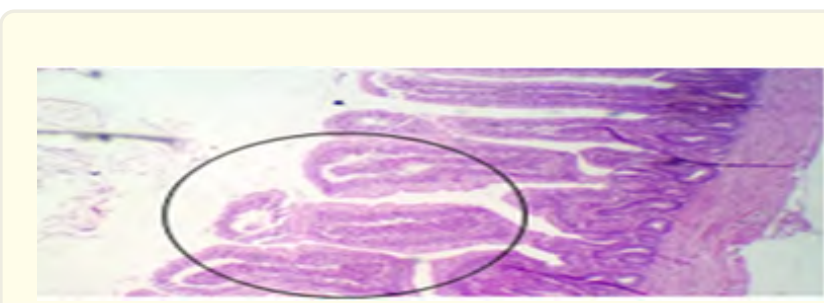

Figure 3: Intestine of infected broilers by cl perfringens showing necrotic epithelial lining villi and desquamation (open arrow) H\&E X 100.

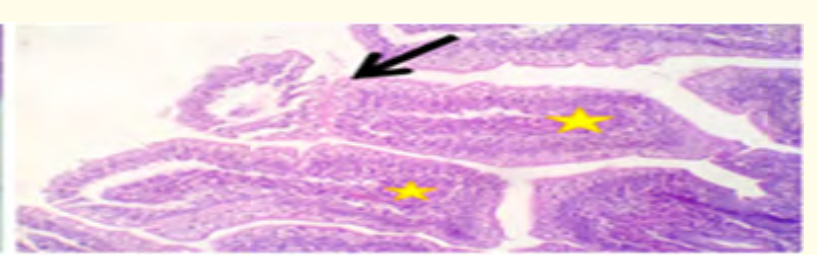

Figure 4: Intestine of infected broilers by cl perfringens showing necrotic epithelial lining villi and desquamation (arrow) and presence of heterophilic and lymphocytic infiltration in the lamina propria and submucosa (yellow stars) H\&E X100. 


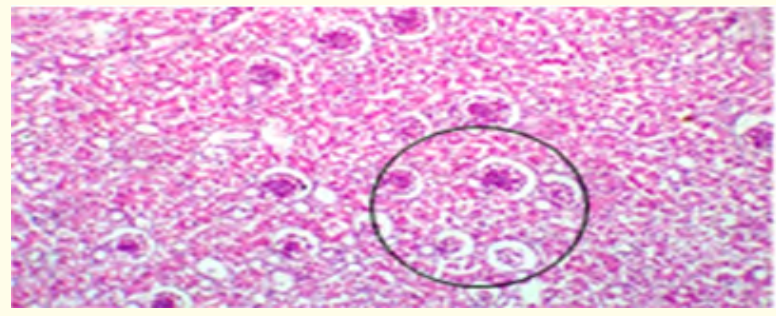

Figure 5: Kidney of infected broilers by cl perfringens showing subscapular aggregation of lymphocytes (star). the renal papillae showing perivascular edema (open arrow).

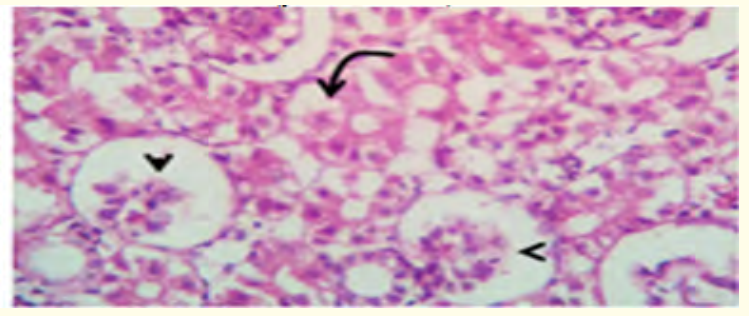

Figure 6: Kidney of infected broilers by cl perfringens showing shrinkage of moderate number of the glomeruli (arrow heads) and degenerative changes mainly hydropic degeneration in renal tubular.

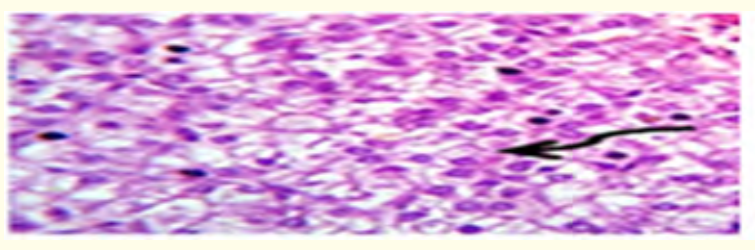

Figure 7: Liver of infected broilers by $\mathrm{cl}$ perfringens treated with lincomycin and kitasamycin together showing normal structures with mild hydropic degeneration (curved arrow) in some hepatocytes. H\&E X 100.

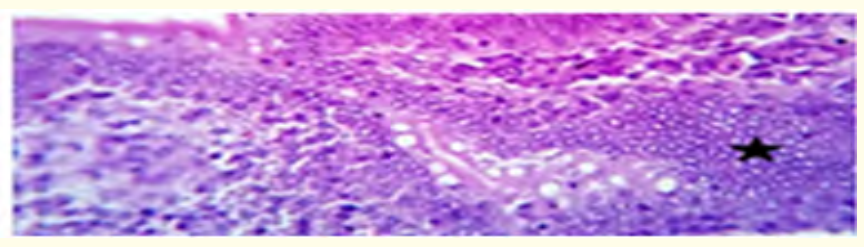

Figure 8: Intestine of infected broilers by cl perfringens treated with lincomycin and kitasamycin together showing normal structures, focal villous basal cells proliferation (star) H\&EX 100.

Treatment infected broilers by lincomycin or kitasamycin either alone or together were effectiv and resulted in disappearance of clinical signs and improved body performance, leukogram, phagocytosis \%, phagocytic index toward to nearly normal beside improved in pathological lesion (table 1-6)... Disappearance of clinical sings and improvement body performance leukogram, phagocytosis \%, phagocytic index post treatment by lincomycin and kitasamycin might be due to reduction reisolation and suppress clostridium perferenges invade host [2]. Kitasamycin play an a role in controls clostridium perfringens infection in broilers and improved clinical signs and improve body performance [41]. These results agreed with those stated [3] mentioned that Cl. Perfringens sensitive to lincomycin. In addition [6] found that kitasamycin is effective against clostridium perfringens infection leading to disappear clinical signs and improved hemato-biochemical parameters. lincomycin is effective in treatment clostridium perferenges infection in chickens leading to improved clinical signs and body performance [4 \& 21]. lincomycin decreased incidence of necrotic enteritis in broilers so improved leukogram, phagocytosis \%, phagocytic index, protein picture, lipid profile, liver enzymes, kidney function, catalase, super oxide dismutase and malanodialdhyde return to normal levels [20].

It could be concluded that necrotic entrititis in broilers induce some adverse effect on hematobiochemical parameters and this adverse effects were returned to the nearly normal levels post treatment with lincomycin or kitasamycin either alone or together but combination of both drug have supperior effect in clostridium perfringens. So, its good using combination of lincomycin and kitasamycin in treatment clostridium perfringens. 


\section{Acknowledgment}

The authors thank Dr. Abo El -Fetouh, E.H senier researcher, Animal Health Research Institute, Zagazig Branch for his help in histopathological study.

\section{References}

1. Abdalla $\mathrm{O}$ and Emam E. compatibility of diclazuril and lincomycin in broiler chickens. Zag. Vet. J 33.2 (2006): 147-161.

2. Abdel Aziz M. Hand Book of Veterinary Pharmacology 5th Ed Faculty of Vet. Medicine, Zag. Uni (2002).

3. Abd El-Hamid H., et al. "Pathogenicity and antibiotic sensitivity of Clostridium perfringens isolates from chickens in El-Behera governorate, Egypt”. Life Sci. J 12.5 (2015): 174-182.

4. Abd El-Monsef A. Concurrent uses of diclazuril and lincomycin for control of necrotic enteritis in broilers. MSc. Thesis submeted Fac. of Vet. Med., Zag Univ (2016).

5. Abd El-Monsef A. Untraditional treatments for controlling Clostridial infection in broilers. PHD Thesis submeted Fac. of Vet. Med. Zag Univ (2019).

6. Abo-Zaid 0. "Efficacy of kitassmycin and amoxicillin on chlosterdial infecti-ons in broiler chickens". MVSc. Thesis submeted Fac. of Vet. Med, Zag Uni (2017).

7. Adel A. some pharmacological studies on synbiotic and phytobiotic. M. Sc. Thesis (pharmacology) Fac of Vet Med, Zagazig University (2018).

8. Alaeldein M., et al. "Effect of organic acid and probiotic on growth, blood metabolites and antioxidant status in finishing broilers challenged with cl perfringens". The J of Animal \& Plant Sci 27.4 (2017): 101-107.

9. Ali Z., et al. Isolation, Character-izat-ion and Pathogenicity of the Most Common Bacteria Associated with Gut Health in Egyptian Broiler Chicken Flocks. International J. of Vet. Sci 10.3 (2021): 999-1012.

10. Allain, C., et al. Enzymatic determi-nation of total serum cholesterol. Clin. Chem 20.4 (1974): 470-5.

11. Allam H., et al. "Immunobiochemical and pathological studies on necrotic enteritis in pekin duckling with trail of treatment". Mansoura Vet. Med. J 12.2 (2013): 45-53.

12. Alouf J and Jolivet C. "Purification and characterization of Clostridium perfiingens delta toxin". Infect. Immun 31.2 (1981): 536546.

13. Baha I., et al. "Closteridial population and the intestinal lesions in chickens infected with clostridium perifringes and Eimeria necatrix". Vet Microb 54.3-4 (1997): 301-308.

14. Bancroft J and Gamble M. "Theory and practice of histological technique". 5thEd livingston, London, Edinburgh, New york, Phildadelphia, St Louis, Syndeg (2002).

15. Craven S., et al. Incidence of C. perfringens in broiler chickens. Avian Diseases 45 (2001): 887-896.

16. Cruickshank R., et al. Medical Microbiology (2) Practice of Med. Microbiology.12thEd. Churchil Livingstone, London (1975).

17. Doumas B., et al. "A candidate reference method for determination of total protein in serum". Clin. Chem 27 (1981): 1642.

18. Doxy D. Veterinary clinical pathology. 18th ed., London (1983): 56-60.

19. Eid S., et al. "Prevention of Necrotic Enteritis in Broiler Chickens by Prebiotics and Probiotics VS Control by Antibiotics, in Vivo Study". AJVS 64.1 (2020): 143-153.

20. Elkomy A., et al. "Comparative studies on efficacy of lincomycin and bacitracin for the control of necrotic enteritis in broiler chickens". International J. of Basic and clinical Pharma 8.6 (2019): 1153-1158.

21. El-Shahat I. Efficacy of some drugs in broiler chickens. PHD Thesis Fac of Vet Med(Moshtohor), Benha Uni (2019).

22. Felipe M., et al. "Antimicrobial susceptibility of Clostridium perfringens isolated from piglets with or without diarrhea in Brazil". Braz. J. Microbiol 43.3 (2012): 231-242.

23. Fossati P., et al. "Use of 3, 5-dichloro-2-hydroxy-benzene sulfonic acid/4-aminophenazone chromagenic system in direct enzymatic assay of uric acid in serum and urine". Clin. Chem 26.2 (1980): 227-231. 
24. Fukata T., et al. "Influence of bacteria on Clostridium perfringens infections in young chickens”. Avian Dis 35.1 (1991): 24-27.

25. Giguère S. "Lincosamides, pleuromutilins, and streptogramins". Antimicrobial therapy in veterinary medicine, 4th ed (2006): 179-184.

26. Henry R., et al. Clinical Chemistry: Principals and Techniques Harper and Row, Hagrstown (1974): 437-440.

27. Herbert A. Macrolide antibiotic in food-animal health. Summary expert opinion on investigation drugs 6.2 (1997): 103-118.

28. Hesong G., et al. "Controlling of growth performance, lipid deposits and fatty acid composition of chicken meat through a probiotic during Cl perfringens infection". Lipids Health Dis 16 (2017): 38.

29. Husdan H and Rapoport A. Estimation of creatinine by the Jaffe reaction. A comparison of three methods. Clin Chem 14.3 (1968): 222.

30. Jain N. Schalm's Veterinary Hematology. 4thEd, Lea and Fibiger, USA (1986): 834.

31. Jayalakshmi K., et al. "A review on antimicrobial resistance, diagnosis and an alternative approach". J. of Ento and Zoo. Studies 9.1 (2021): 1058-1071.

32. Jean D., et al. “Oxidative stress response in Clostridium perfringens”. Microbiology 150 .6 (2004): 1649-59.

33. John D. laboratory determination of alkaline phosphatase. 9th Ed (1982): 580-581.

34. Kaneko J. "Clinical biochemistry of domestic animals". 6th Ed (1989).

35. Khairy M., et al. "Effect of phytobiotic, Sodium butyrate compared to ampicillin in control necrotic enteritis in broiler chickens". Solv. Vet. Res 55.20 (2018): 45-55.

36. Kasab H. "Epidemiology of $\mathrm{Cl}$ perfringens and $\mathrm{Cl}$ difficile among Ontario broiler chicken flocks". PHD Thesis Fac of Vet Med, Uni of Guelph (2017).

37. Chemical basis of the sulfo-phospho-vanillin reaction for estimating total serum lipids". J. Clin. Chem 18.3 (1972): 199-202.

38. Kosar G., et al. "Differential expression of intes-tinal genes in necrotic enteritis challenged broiler chickens with 2 different Clostridium perfringens strains". Poultry Sci 100.3 (2021): 345-354.

39. Krüger M., et al. "Effects of lactulose on intestinal microflora of periparturient sows and its piglet". Curr. Issues Intest. Microb 3 (2001): 1-14.

40. Mabrouk M. "Concurrent use of ciprofloxacin and metronidazole for control of some bacterial infections in broilers". PHD Thesis, Fac of Vet. Med Zag Univ (2016).

41. Martel A., et al. "Susceptibility of Clostridium perfringens strains from broiler chickens to antibiotics and anticoccidials". Avian Pathology 33.1 (2004): 3-7.

42. Nielsen F., et al. "Plasma malondialdehyde as biomarker for oxidative stress. Reference interval and effects of life style factors". Clin Chem 43.7 (1997): 19-24.

43. Nishikimi M., et al. "The Occurrence of superoxide anion in reaction of reduced phenazine methosulfate and molecular oxygen". Bioch Bioph Res Com 46.2 (1972): 849-54.

44. Rajkumar P and Subrnian N. “Determination of Lincomycin hydroc-hloride and pharmaceutical formulations”. Inter J. Chem Tech Res 2.4 (2010): 2052-2055.

45. Reitman S and Frankel S. “Calorimetric determination of transaminases activity”. Am. J. Clin. Path 28 (1957): 56.

46. Rouse B., et al. "Neutrophils in antiviral inhibition of virus replication of mediators produced by bovine neutrophils". J.Inf. Dis 141.2 (1980): 223-232.

47. Rubin B and Tamaoki J. “Macrolide antibiotics as biological response modifiers”. Curr Opin Investig Drugs 1.2 (2000): 169-172.

48. Salah M., et al. "Effect of humic acid on growth performance, immunological, some blood parameters and control intestinal closterdium in broiler chickens". Zag. Vet. J 43.1 (2015).

49. Sayed A., et al. "Concurrent use of ciproflox-acin and metronidazole for controlling of some bacterial infections in broiler chickens”. Benha Vet Med J 31.2 (2016): 83-92.

50. Sinha K. "Colorimetric assay of catalase". Anal Biochem 47.2 (1972): 89-94. 
51. Steven R. "A framework for assessing the efficacy of antimicrobials in the control of necrotic enteritis in broiler chickens". J of Appl Poultry Res 24.2 (2015): 46-56.

52. Sungtaek h., et al. "Growth-Promoting and Antioxidant Effects of Magnolia Bark Extract in Chickens Uninfected or Co-Infected with Clostridium perfrinens and Eimeria maxima as an Experimental Model of Necrotic Enteritis”. Curr Dev Nutr 2.4 (2018): nzy009.

53. Tamhane and Dunlop. "Statics and data analysis from elementary to interme-diate". Upper Saddle River, USA (2000).

54. Thompson R., et al. "Live attenuated vaccine-based control of necrotic enteritis of broiler chickens". Vet Microbiol 113.1-2 (2006): 25-34.

55. Timothy F, et al. “A Review of Antibiotic Use in Food Animals: Perspective, Policy, and Potential”. Public Health Rep 127.1 (2012): 4-22.

56. Titball R., et al. "The Clostridium perfringens alpha toxin". Anaerobe 5.2 (2000): 51-64.

57. Wahlerfeld A. In methods of enzymatic analysis, HU Bergmeyer, Ed. Academic Press, New York 5 (1974): 1831-1835.

58. Woldehiwet $\mathrm{Z}$ and Rowan T. "Effects of age of calves on phagocytosis and killing of Staph aureus by polymorphonuclear leucocytes". Br. Vet. J 146 (1990): 165-170.

Volume 2 Issue 2 February 2022

(C) All rights are reserved by Hala M Kalill., et al. 